\title{
THE PREGNANT MUSE: Language and Birth in "A Song of the Rolling Earth"
}

\author{
JAMES D. GRIFFin
}

AN IMPORTANT value of Walt Whitman's "Song of the Rolling Earth" is its ability to amplify and explain a recurrent concern in Whitman for words not found in books and for things that are said to be "words." The poem also explains how, for Whitman, this notion is linked with the idea of a fertile "mother" earth. Both of these notions are a commonplace in the Leaves of Grass: "There is that in me," writes Whitman in his "Song of Myself," which is "without name-it is a word unsaid" and "is not in any dictionary." This is the same something which, in "A Song for Occupations," "eludes discussion and print," which "is not to be put in a book." Later, in "Outlines for a Tomb," a name is described as "an earth, with mountains, fields and tides," and in "Kosmos" a person (who "is" the earth's coarseness and sexuality) is said to use "the theory of the earth" to understand all other theoriesthis "by subtle analogies." Nowhere in the Leaves are those "subtle analogies" or, indeed, the "theory of the earth" itself more clearly and fully presented than in "A Song of the Rolling Earth." And hence the importance of the poem; since these two tropes - the unprintable word and the fertile earth mother-are so prevalent in the Leaves, and since they are here so carefully laid out and explained, a close look at the language of the "Rolling Earth" would seem a promising task indeed. ${ }^{2}$ It is here, if anywhere, that Whitman "makes the dictionaries of words that print cannot touch."3

Even as the poem begins, Whitman sets out his first definition, a crucial distinction between words and Words. ${ }^{4}$ This is "a song of the rolling earth," he says in line 1, "and of words according." But words that "accord" with the rolling earth "are in the air, they are in you" (1. 4). And again, in the second stanza, the "delicious sounds out of your friends' mouths" are not "words," for "real words are more delicious than they." The opening two lines, dropped in 1881, make the point more explicit:

\footnotetext{
Earth, round, rolling, compact - suns, moons, animals all these are words,

Watery, vegetable, sauroid advances-beings, premonitions, lispings of the future-these are vast words. ${ }^{5}$
}

Whitman is operating here within the ancient tradition of The Word as a cosmic reason. The tradition, which of course stems from Greek philosophy, would see the celestial bodies and the animals, each in its place, as expressions of a basic $\lambda$ óros, which is the source of world order and intelligibility. This tradition is present as well in the gospel of John, where "the Word" is the 
self-revealing thought and will of God, and is most often associated with the second person of the Trinity. ${ }^{6}$

Expanding on this tradition, the third stanza emphasizes the difference between "a word" and "my name." Human bodies are "myriads of Words" (1. 7), and each of the four elements are words (1. 10). "My qualities," says Whitman, "interpenetrate with theirs" (with those of the four elements), and "my name is nothing to them" (1. 11). If matter is "words" then Whitman is composed of "myriads of Words"; if "air, soil, water, fire" are words, then "I myself" am truly the Word made flesh. "My name is nothing to them" (the elements) because it is not a Word. And yet these primordial Words can be developed into more complex utterances: thus it is that "a healthy presence, a friendly or commanding gesture" and "the charms that go with the mere looks of some men and women" are complete "sayings" and "meanings" (11. 13-14); they are complex clusters of Words that can be interpreted. Beyond even these, lie the "masters" of line 16, men whose tools are "those inaudible words of the earth" (1.15).

We must be careful to read the word master here as a reference not only to the "workmanship of souls" (emphasis mine)-as a reference to the "master" as workman in a craft - but also to the tradition of master as teacher or sage, for his is a "workmanship of souls" (mine again). Even in a trade, the "master" is one who is qualified to teach apprentices, as well as to carry on his craft independently. There is here, then, a progression from single "words" to complete "sayings" and then to the skilled "masters" who "use" words effectively. But the final step is "amelioration"-the workmanship of the earth itself. Like the craftsman, the earth is also concerned with "attributes, growths, effects," but unlike the work of the human master, its "defects and excrescences" are also beautiful. For Whitman to say so is to appeal once again to the existence of a dimly understood universal $\lambda$ ó $\gamma \circ \varsigma$, or divine plan. The "Manuscript Notebook-2" offers a gloss:

Amelioration is the blood that runs through the body of the universe. $-\mathrm{I}$ do not lag $-\mathrm{I}$ do not hasten - I bide my hour over billions of billions of years - I exist in the void that takes uncounted time and coheres to a nebula, and in further time cohering to an orb, marches gladly round, a beautiful tangible creature, in his place in the processions of God. . . 7

Whitman uses "amelioration," then, to identify the seminal life force, the "blood," of an evolving universe and, by extension, of the evolving earth. ${ }^{8}$ His is a great she-universe: It has a "body" in which blood flows, and within its "void" a new creature is formed. Nor is it surprising, in light of this, that Whitman's earth also takes on a feminine character. It is described as a "great mother," and by its very roundness (its "greatness") it proclaims its fecundity. For this reason too, the earth has all its attributes "latent in itself from the jump" (1. 19), and it is characterized by "excrescences" and "growths" (11. 20, 19). But the notion of the earth as a great mother is not here an empty conceit. In fact, it is central to Whitman's purpose, and this becomes very clear 
when, in lines 28 through 30, a pun in the French plays on the notion of pregnancy while, at the same time, reintroducing the central motif of the Word:

\author{
(Accouche! accouchez! \\ Will you rot your own fruit in yourself there? \\ Will you squat and stifle there?)
}

Blodgett and Bradley, in a footnote, gloss line 28 as, "French: properly 'Accouchée! accouche!'-i.e., 'You pregnant one! be delivered.' 'I'll admit I'm puzzled by this. The more obvious translation would, I think, be two imperatives, one familiar and one polite (or plural); it honors the text and it works fine. I'd hesitate to say the editors are wrong but, to me at least, it is not clear why it is "proper" to tack on an extra letter and supply a "missing" accent mark-especially to produce a peculiar exclamation like, "You pregnant one!" Is this a shout? Admittedly, Whitman is not backward in his use of exclamation marks, and even later in this same poem we find the sentence (?) "Whoever you are!" but, still, why meddle with the text? And even supposing that "accouche!" were a noun with a missing accent mark, are we obliged to assume that it is feminine as well? An accouchée is indeed a woman in childbed, and men of course do not as a rule get pregnant. But after all, Whitman is probably addressing himself here (hence the parentheses), and so the (surprising) masculine form of this noun could be taken as a clue to his meaning. Blodgett and Bradley translate "accouchez!" as "be delivered!" and this certainly makes sense in the context but, again, the more obvious translation is quite different. Accoucher does mean "to be confined," and "to be delivered of; to give birth to," but it also means "to speak out." The Grand dictionnaire Garnier specifically translates Accouchez! as "out with it!"9

Out with it! The injunction makes a great deal of sense from a man who, just one line before, has said: "II utter and utter, / I speak not." In a sense, Whitman is himself pregnant with Words he cannot deliver. "To bear, to better," this is his declared purpose, for "In the best poems re-appears the body, man's or woman's, well-shaped, natural, gay" (1. 8). Isn't this Whitman's attempt to produce that body? "Human bodies," he tells us, "are words" (1. 7). The question in line 29, "Will you rot your own fruit in yourself there?" would also, on this reading, be directed inward at Whitman himself. Line 30 ("Will you squat and stifle there?") seems to be directed to the Embryo itself. At very least, Whitman is playing midwife to the Words and Meanings that he shares with the earth, Words which "interpenetrate" them both.

That this view is clearly within the spirit of the poem as a whole is evident from the fact that the earth is herself pregnant with meanings. While Whitman's poetic attempts abort themselves in audible words, the earth "has no conceivable failures" (1. 34). And, as we have noted, it has all "growths" and is "latent in itself from the jump," with sexual connotations 
perhaps in "the jump." The Words of the "great mother" never fail "her children" (1. 41). Whirling through space, the earth is said to be "carrying" her burden (1.66). And finally, in language that evokes the womb, there is a "fluid vacuum around and ahead" with "No balk retarding, no anchor anchoring, on no rock striking" (11. 68-69). It is of course possible to take these things too far, and yet the vision of the earth as a fertile mother who "possesses" something quietly "underneath" (1. 37) occurs too often (and works too well) to be safely ignored.

Thus, the lines that follow the "Accouche! accouchez!" of line 28, complete the movement from "delicious sounds" to a "workmanship" of the earth's "inaudible words." The earth, we learn, is "dumb" and it "does not argue": It does not "promise" or "persuade," and it does not "threaten" or "scream" (11. 31, 33); instead, it "possesses still underneath." At this point, the "word" trope reaches its full development. Paradoxically, the earth posessess both "still" and "words," both of which are contrasted with "ostensible sounds" - so the word "still" has several functions here; the earth:

\author{
possesses still underneath, \\ Underneath the ostensible sounds, the august chorus of \\ heroes, the wail of slaves, \\ Persuasions of lovers, curses, gasps of the dying, \\ laughter of young people, accents of bargainers, \\ Underneath these possessing words that never fail. [11. 37-40]
}

The earth possesses a sort of quiet (a "still") underneath the "ostensible sounds" of lines 38 and 39. It does not use audible words. But it also possesses a serenity (again, a "still"). Above are "wails," "persuasions," "curses" and "gasps," underneath, a tranquility. And finally, although the earth "shuts none out," it possesses "still underneath" those Words that "never fail." (It possesses them, that is, constantly and always.) Thus the "ostensible" words of this stanza draw upon the meanings of the earth, but they can never deplete those meanings. The implied disjunction between "possesses still" (1. 37) and "possessing words" (1. 40) complements the antithesis inherent in a reference to "the words of the eloquent dumb great mother" (1. 41). This paradox need not puzzle us. We are already familiar with Whitman's distinction between words and The Word or hópos - and that is precisely the distinction at work here.

But not until line 42 are we introduced to "motion" and "reflection," the real sources or mainsprings of the earth's "true words." As the first section draws to a close, Whitman "defines" and illustrates these terms, not only in reference to the earth, but also with an eye on the universe of stars. There is motion, for example, in the universal dance and courtship of the "ceaseless cotillons" (1. 45), and there is reflection in the mysterious "character of a mirror" (1. 51). The "interminable sisters" of line 44 are, it would seem, the infinite heavenly bodies and their motions. "The beautiful sister we know," 
the earth, "dances on with the rest" (1. 47). In her hand she holds something that reflects her image, and "her eyes glance back from it" (1. 51). The moon, we infer. It has the character of a mirror in that it shows a face and glances back. It is held, like all the sisters, by "the centripetal and centrifugal" forces (1. 46), both of which act simultaneously on all bodies as they orbit. Thus "the twenty-four," the hours, are said to "approach and pass," as in a dance, "with their companions or a companion" (1. 56). Those with "their companions" would seem to be the night hours, with their multitudes of stars and with the moon; those with "a companion" would be the hours of daylight, accompanied by the sun alone.

But this is a paradoxical cosmology. These twenty-four sisters are both "seen" (1. 54) and "looking" (1. 57) from (and through) the "countenances" of others. They look through the countenances of "those who are with them"children, women, men, animals, landscapes, waters - and they are seen by ourselves. At once seen and looking, "our countenances" are "faithfully returning [re-turning?] them" (1. 61). To make matters worse, the hours appear in public every day, "but never twice with the same companions" (1. 62). Like the paradox of the "eloquent dumb great mother," this problem is resolved by an appeal to the immutable. The "twenty-four" are never twice with the same companions, in part, because we die; and we can serve as the eyes of the universe in the same sense that we can speak its language.

But there is yet another paradox in Whitman's universe. The fact that the twenty-four sisters "approach and pass" suggests a Ptolemaic universe, while the fact that "the three hundred and sixty-five" proceed "resistlessly round the sun" (1. 63) argues a Copernican one. Properly understood, the notion of the "cotillons" (1. 45) resolves this dual cosmology. The cotillon (or cotillion) is, of course, a square dance of French origin and is composed of five figures performed by four couples in $6 / 8$ or $2 / 4$ time. The idea of a cotillon, then, not only describes the spinning of the earth on its axis (the twirling of the couples themselves) and the rotation of the earth around the sun (the clockwise movement of the couples on the dance floor), but it also explains how "the twenty-four" can be said to "approach and pass," while "the three hundred and sixty-five" move round the sun-for in the cotillon, each couple is both an axis on which all the other dancers turn and, at the same time, can "orbit" on the axes of others. Whitman's sister earth has "her ample back towards every beholder" (1. 48) because, in one sense, she dances with the moon which she is "holding up" (1. 51). But in a more important sense she is "embracing man, embracing all" (1. 63) as her dance companion.

The second section of the "Rolling Earth" is addressed to "you," but - as usual in the Leaves - this is the singular you, "whoever you are," the solitary reader. The distinction between the singular and the plural (collective, hence social) you is especially important in this poem. It explains, for example, 
why the poet would write a gospel proclaiming that "Each man to himself and each woman to herself" is the "true word" (1. 79). This is not a retreat from the offer of physical and spiritual communion that we rightly associate with the good, gray poet; it is, rather, the advice of the poet as shaman. The inward-directed gaze, tied as it is to growth in this poem, recalls the almost narcissistic, even androgynous quality of the eloquent dumb great mother who begets Words while "inviting none, denying none, / Holding a mirror day and night tirelessly before her own face" (11. 52-53).

And yet the often-quoted third section has never, that I am aware of, been interpreted in light of this narcissism of the earth. More often than not, critics of this section have been reading furtively over Emerson's shoulder - a highly rewarding approach, I should add. Nevertheless, the ideas here can be placed in another context:

\section{I swear the earth shall surely be complete to him or her who shall be complete, \\ The earth remains jagged and broken only to him or her who remains jagged and broken. [11. 90-91]}

If the fertile earth invites and denies none and gazes at its image day and night, and if we are to emulate the earth, then to "be complete" carries the suggestion of androgyny. We are to beget and deliver "true words." In any case, it is clear that we are to use the earth as our model. Man's greatness and power must emulate that of the earth (1. 92). All theories must corroborate "the theory of the earth" (1.93). The diverse concerns of man must compare with the amplitude of the earth; they must "face" the "exactness, vitality, impartiality, rectitude of the earth" (11. 94-95). And it is this asexual earth, one which is "latent in itself" and which "contains itself," that provides us with a model for "love" in this poem as well.

Blodgett and Bradley read "to 'promise back' love" for "that which responds love" in line 96, and this interpretation works rather well. But if Whitman is drawing a distinction between "that which responds love" and "that which contains itself, which never invites and never refuses" (1. 97), then perhaps he simply means "that which responds to love" (as in orgasm, for instance). This would explain his reference to "sweeter spasms" in "that which contains itself" (11. 96-97), and it would eliminate the need for a fancy explanation based on Latin roots. But no matter how we resolve the "responds love" problem, the general drift of the passage is clear enough. The description in line 97 of a love which "never invites and never refuses" points directly to the earth-love of line 52, and a love which "contains itself" is the love of a poet who can say "my qualities interpenetrate" with those of the earth. "The best," says Whitman (and here he is in accord with his eloquent mother), is "always to leave the best untold."

Finally, in lines 104 through 107, the "untold" merges again with the unborn and, again as well, it harkens back to the protracted labor of the ac- 
couche! sequence: that "my breath will not be obedient to its organs" almost suggests a labored parturition; and "I become a dumb man" (1. 107) clearly echoes the "eloquent dumb great mother" of line 41. Like the earth, Whitman here achieves the ironic synthesis of eloquence and dumb show-if "there is no greatness or power that does not emulate those of the earth," and if Whitman can emulate the earth's dumb-greatness, then in fact, he may inherit as well its fecundity and expressiveness. In the final stanza of this section, the poet at last sounds decisive and self-assured, and here a final putting-back-together is also envisioned:

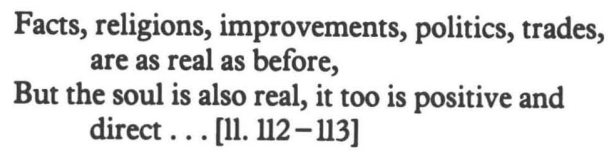

In order for us to summarize, then, the roles that Whitman has assumed in these three sections, we must see him as a "master"-teacher, as a "master"craftsman and as a midwife to the earth. But more even than a master or midwife, Whitman is in the end a celebrant. His poem, after all, is "A Song of the Rolling Earth" with evolution as its lyric. And in the closing stanza, Whitman is at last at the podium. "Sing on, singers!" we hear him cry. (Out with it!) And when, facing the earth, Whitman raises his baton, the earth begins to "roll" out loud as drums roll or as thunder rolls - we hear the timpani of those "substantial words" that exist "in the ground and sea."

\section{University of California, Berkeley}

\section{NOTES}

1 "Song of Myself," 11. 1309, 1312-1313; "A Song for Occupations," 11. 45-46; "Outlines for a Tomb," 1. 43; and "Kosmos," 11. 2, 7, in Leaves of Grass, Comprehensive Reader's Edition, edited by Harold W. Blodgett and Sculley Bradley (New York: New York University Press, 1965), pp. 88, 213, 381, and 392.

2 More important, this remarkable poem deserves our attention for its own merits. It is much neglected, but see Hugh l'Anson Fausset, Walt Whitman: Poet of Democracy (rpt. New York: Russell \& Russell, 1942), pp. 155-158; and Suzanne Poirier, "'A Song of the Rolling Earth' as Transcendental and Poetic Theory," Walt Whitman Review, 22 (1976), 67- 74.

3 "A Song of the Rolling Earth," in Leaves, 1. 101; all further references to this poem appear in the text, pp. $219-225$.

4 Throughout this paper I use the upper case to distinguish a metaphysical use from the conventional one.

5 Leaves, pp. $218-219$ n.

6 The editors cite John 1.1 as a gloss to line 19. See also John 1.14 and 6.63, James 1.21-23 and Hebrews 11.3. 
7 Emory Holloway, editor, The Uncollected Poetry and Prose of Walt Whitman (Garden City: Doubleday, 1921), 2:79-80.

8 Gay Wilson Allen is right when he identifies the "sauroid advances" and "lispings of the future" with the "cosmic processes" of evolution; The New Walt Whitman Handbook (New York: New York University Press, 1975), p. 246.

9 “Accoucher," Grand dictionnaire Garnier (Paris: Editions Garnier Frères, 1974). Likewise, "accouche! -spit it out!, out with it!" Collins Robert, 1978 edition. 